\title{
Digital Literacy Analysis of Elementary-School Students in Malang
}

\author{
Farida Nur Kumala*, Cicilia Ika Rahayu Nita, Arnelia \\ Dwi Yasa \\ Universitas PGRI Kanjuruhan Malang \\ Malang, Indonesia \\ *faridankumala@unikama.ac.id, cirn@unikama.ac.id
}

\author{
Anik Ghufron, Pratiwi Pujiastuti \\ Universitas Negeri Yogyakarta \\ Yogyakarta, Indonesia \\ anikghufron@uny.ac.id, pratiwi@uny.ac.id
}

\author{
Chandra Puji Rahayu \\ SDN Jenggolo Kepanjen \\ Malang, Indonesia \\ candrapujir@gmail.com
}

\begin{abstract}
This study aims to determine the literacy skills of elementary school students in Malang. The subjects of this study were 10 elementary school students in Malang with a total of 303 samples. Data were collected using a questionnaire instrument. This research uses a descriptive quantitative approach. The results showed that the aspect of searching on the Internet (Internet Searching) was classified as high with an average score of 3.45, the guidance aspect of hypertext (Hypertext Navigation) was sufficient with an average score of 2.83 . 3). The evaluation aspect of the information content (Content Evaluation) is quite adequate with an average score of 3.14. 4). Aspects of the preparation of knowledge are sufficient with an average score of $3.10,5)$. Communicating search results gets an average score of 2.87 in the sufficient category. Based on the results obtained, it can be concluded that the overall average value of digital literacy of elementary school students in Malang City with a score of 3.07 is in the sufficient category. Students' digital literacy skills enable students to use information wisely and appropriately in their daily lives.
\end{abstract}

Keywords—digital literacy, elementary school, internet usage

\section{INTRODUCTION}

The use of digital media is increasing from year to year. Based on data from[1], it is stated that internet users in Indonesia come from all age groups, including children. Currently children are good at using mobile phones. However, based on research results, $83 \%$ of internet use is for searching commercial sites, $6 \%$ for looking for assignments [2], $85 \%$ for watching videos and $10 \%$ for studying [3], $87.4 \%$ for accessing social networks, $68.7 \%$ searching, $59.9 \%$ instant messaging, $59.7 \%$ looking for the latest news, $27.3 \%$ downloading and inspiring videos [1].

Excessive use of mobile phones will result in problems, one of which is the use of the internet to search age-inappropriate content [4], cyberbullying [5,6], cybercrime and violence among adolescents [7,8], declining adolescent morals [9], abuse of technology [10], reduced enthusiasm for learning $[11,12]$ and decreased student learning scores $[13,14]$; as well as making children addicted to playing cell phones and interfering with daily activities [15], affecting children's psychology and development [16], gadget addiction [17,18], ethics, mind-set, children's perspective, the ability to get a job and more broadly affect the social and cultural conditions in society [19], the spread of hoax news and even terrorism [20].

One of the problems that occurs is the environment that is not balanced with the ability to choose the right information. This ability is known as digital literacy. Digital literacy is very important for children in choosing the right information or content from the internet, so that they can develop children's abilities to use information wisely. As a result, it is important to do planting and habituation so that children are able to have digital literacy skills and avoid problems caused by the internet.

Digital literacy is the ability to understand and use information concepts in many formats from various sources through computers [21], the ability to use digital media, communication tools or networks to find, evaluate, use, create information and make wise use of it $[22,23]$. Digital literacy is also the ability to use digital devices involving technical skills and cognitive intelligence [24,25]; digital literacy as a protective tool for digital media [26,27]. So digital literacy requires a process of thinking and doing information found through digital media [7].

Digital literacy consists of several indicators, namely [21]: 1) Searching on the Internet is a person's ability to use the internet to carry out various activities in which the competence of searching on the internet has indicators that measure, among others: the ability to search for information on the Internet and 
perform various activities there in. 2) Hypertext guidance is the ability to read and understand information in hypertext or multimedia format [28]. In internet search competence has several sub indicators that measure, among others: knowledge of hypertext and how it works, knowledge of differences in reading textbooks and browsing via the internet, knowledge of how the web works including http, html and url, and the ability to understand characteristics web page.

The third indicator, namely the evaluation of information content, is a person's ability to be critical and provide an assessment of what is found online accompanied by the ability to identify the completeness and validity of the information [21]. In the competency of evaluating information content, there are several indicators that measure, among others: a) The ability to distinguish between the appearance of information content on the web, b) The ability to search for sources and information creators, c) The ability to know the web address. The fourth indicator, namely the preparation of knowledge, is the ability to assemble and build a collection of information obtained from various sources with the ability to collect and evaluate facts and opinions well [21]. In the competency of compiling knowledge, there are several sub indicators, including: the ability to search for information via the internet, the ability to double-check the information obtained, the ability to use several types of media to assess the correctness of information, the ability to compile knowledge from sources taken from the internet.

The fifth indicator is communicating the information. Communicating the information is an activity where students convey the knowledge obtained through observation to association, both written and oral. In the competency of communicating findings, there are several indicators that measure, including: presenting findings in writing and fattening of findings in writing.

Digital literacy can create a community structure with critical and creative views and patterns of thought [19], because digital literacy affects children's psychology [16], motivates and influences learning outcomes [7,29-31], digital literacy will overcome excessive knowledge of technology for students [32], digital literacy functions as intelligent information for students [33].

A person who has digital literacy skills is able to understand the use of technology effectively to achieve a goal, will not be easily consumed by provocative issues, become a victim of hoaxes, or a victim of digital-based fraud. Digital literacy involves mastering ideas instead of pressing buttons and there is information evaluation, analysis and clever synthesis of using information. Digital literacy develops students' abilities in filtering information on mobile phone [21].

It is important to develop digital literacy by teachers and parents, because teachers and parents can practice digital literacy skills through daily activities both at home and at school. Habitual routine will make a culture for someone. Culture is a system of meanings and symbols that include values, norms, beliefs, traditions, rituals, ceremonies and myths that are translated by a certain group of people [34]. These symbols are like a written (explicit) and hidden (implied) message encoded in the language. The symbolic meaning is the result of interpreting experiences to guide one's actions and is the product of social interaction between members of an organization, which represents the identity of the organization and differentiates one organization from another. Thus, cultural values resulting from student interaction through learning, communication and socialization in the classroom and at home are integrated and are able to influence children's thinking and beliefs.

A person's digital literacy skills can be found through surveys. Based on this digital literacy data, it is used as a basis for giving treatment and follow-up to research subjects. Several analyses of digital literacy skills have been carried out by several researchers including digital literacy analysis at the student level $[12,35,36]$, at the junior and senior high school level [37-39], teenagers [40], teachers [41], elementary school students [42]. There has never been an analysis of digital literacy on elementary school students in Indonesia. It is important to know digital literacy in elementary schools as the basis for students to obtain information and develop the ability to process information at a higher stage.

The purpose of this study was to analyse the digital literacy level of students in 10 SDNs in Malang City. Based on the data from the research results, it can be used as a basis for teachers and parents to improve or develop students' digital literacy skills at the elementary school level.

\section{METHODS}

This research uses quantitative description method. The sample used in this study were elementary school students in Malang with a total of 303 research samples taken from 10 elementary schools. The school was determined randomly, while the student selection was taken purposively, namely all 5 th grade students at the SD. The selection of grade 5 is based on the age level of grade 5 who is quite capable of using the internet well. In this study, the instrument used was a questionnaire in accordance with the digital literacy instrument grid as outlined in table 1.

TABLE I. DIGITAL LITERACY INSTRUMENT INDICATOR [21]

\begin{tabular}{|c|c|c|}
\hline $\begin{array}{l}\text { Variable } \\
\end{array}$ & Indicator & Sub Indicator \\
\hline \multirow[t]{5}{*}{$\begin{array}{l}\text { Digital } \\
\text { Literacy }\end{array}$} & $\begin{array}{l}\text { Internet } \\
\text { Searching }\end{array}$ & $\begin{array}{l}\text { a. The ability to search for information on the Internet } \\
\text { b. Perform various activities in it }\end{array}$ \\
\hline & $\begin{array}{c}\text { (Hypertext } \\
\text { Navigation) }\end{array}$ & $\begin{array}{l}\text { Knowledge of hypertext and how it works } \\
\text { Knowledge of the differences between reading textbooks and } \\
\text { browsing via the internet } \\
\text { Knowledge of how the web works includes http, html, and url } \\
\text { Ability to understand the characteristics of web pages }\end{array}$ \\
\hline & $\begin{array}{l}\text { Evaluation of } \\
\text { content } \\
\text { information }\end{array}$ & $\begin{array}{l}\text { Ability to distinguish between display and information content on } \\
\text { the web } \\
\text { Ability to search for information sources and producers } \\
\text { c. Ability to know the web address }\end{array}$ \\
\hline & $\begin{array}{l}\text { Compilation } \\
\text { of Knowledge }\end{array}$ & $\begin{array}{l}\text { Ability to finding information in internet } \\
\text { Ability to re-check information obtained } \\
\text { Ability to use several types of media to judge the correctness of } \\
\text { information } \\
\text { The ability to compile knowledge from sources taken from the } \\
\text { internet }\end{array}$ \\
\hline & $\begin{array}{l}\text { Communicate } \\
\text { the findings }\end{array}$ & $\begin{array}{l}\text { Disclose the findings in writing } \\
\text { Disclose the findings in an unwritten manner }\end{array}$ \\
\hline
\end{tabular}


The data analysis technique used is descriptive quantitative data analysis technique using a questionnaire. Finding the average value of each variable with the following formula (equation 1.):

$M_{x}=\frac{2 f x}{N}$

Note:

$\mathrm{M}_{\mathrm{x}} \quad=$ the mean should be found

$\Sigma f x=$ the sum of the product of the product between the

midpoints of each interval, with the frequency

$\mathrm{N}$ $=$ Total respondents

Interpreting the average value of the variables obtained above, because the vulnerable value will range from $1.0-4.0$, then based on how to calculate the average value, the qualification provisions in table 2 will be used.

TABLE II. DigITAL LITERACY CRITERIA TABLE [21]

\begin{tabular}{|l|l|l|}
\hline No & \multicolumn{1}{|c|}{ Score range } & \multicolumn{1}{c|}{ Category } \\
\hline 1 & $1,0-1,75$ & Lower \\
\hline 2 & $1,76-2,50$ & Low \\
\hline 3 & $2,51-3,25$ & Midle \\
\hline 4 & $3,26-4,00$ & High \\
\hline
\end{tabular}

\section{RESULTS AND DISCUSSION}

Based on the research results shown in table 3.

TABLE III. DIGITAL LITERACY ANALYSIS OF ELEMENTARY SCHOOL STUDENTS IN MALANG

\begin{tabular}{|c|c|c|c|c|c|c|}
\hline \multirow{2}{*}{$\begin{array}{l}\text { Name } \\
\text { School }\end{array}$} & \multicolumn{5}{|c|}{ Total Score } & \multirow{2}{*}{$\begin{array}{l}\text { Averag } \\
\text { e }\end{array}$} \\
\hline & 1 & 2 & 3 & 4 & 5 & \\
\hline SDN A & 3,67 & 3,22 & 3,64 & 3,48 & 2,33 & 3,50 \\
\hline SDN B & 3,50 & 3,04 & 3,16 & 3,20 & 2,82 & 3,23 \\
\hline SDN C & 3,39 & 3,07 & 3,26 & 3,12 & 2,81 & 3,21 \\
\hline SDN D & 3,53 & 2,73 & 3,27 & 3,24 & 3,12 & 3,19 \\
\hline SDN E & 3,33 & 2,92 & 3,06 & 3,11 & 3,24 & 3,10 \\
\hline SDN F & 3,66 & 2,83 & 3,04 & 2,80 & 3,25 & 3,08 \\
\hline SDN G & 3,24 & 2,87 & 3,12 & 2,96 & 3,14 & 3,04 \\
\hline SDN H & 3,37 & 2,60 & 3,01 & 3,08 & 3,11 & 3,01 \\
\hline SDN I & 3,28 & 2,64 & 3,03 & 3,06 & 2,60 & 3,00 \\
\hline SDN J & 3,50 & 2,33 & 2,85 & 2,85 & 2,33 & 2,88 \\
\hline Average & 3,45 & 2,83 & 3,14 & 3,10 & 2,87 & 3,07 \\
\hline
\end{tabular}

\section{With indicators:}

1. Search the Internet

2. Hypertext Navigation Guides

3. Content Evaluation

4. Compilation of Knowledge

5. Communicating Findings

Based on table 3, it is known that the digital literacy competency level of elementary school students in Malang City is in aspect 1). Searching on the internet can be seen based on the average overall score obtained by an average of 3.45 in the high category, 2). Hypertext direction guidance can be seen based on the average overall score obtained by a score of 2.83 and is included in the enough category, 3). Evaluation of information content can be seen based on the average overall score obtained at 3.14 in the sufficient category, 4). The aspect of compiling knowledge based on the average overall score obtained is 3.10 and is included in the sufficient category, 5). The aspect of communicating the findings can be seen based on the average overall score obtained of 2.87 which falls into the sufficient category. Based on the results obtained, it can be concluded that the overall average value of digital literacy of elementary school students in Malang City with a score of 3.07 is in the sufficient category.

The results of research on digital literacy in elementary school students in Malang City obtained an average score of 3.07 in the sufficient category. Based on the results of the analysis, it shows that elementary school students in Malang City have a sufficient level of digital literacy competence in the aspect of information retrieval of 3.28, and have a sufficient level of digital literacy competence in the aspect of guiding the direction of hypertext, evaluating content, compiling knowledge and communicating findings. Based on these data, it can be seen that, in the information seeking category only who get a high score means that the research subject has been able to search for information from the internet, for other aspects getting enough categories. This may imply that in general the ability to process information is still sufficient. So it can be concluded that the research subject needs to develop the ability to process information from the internet. The ability to process information on the internet is needed to shape student knowledge. Apart from the art of critical thinking, the competencies needed by students are learning how to assemble knowledge and build a collection of information that users get to form new knowledge. Information obtained by users is required to collect and form new knowledge [43].

Digital literacy is important for children to develop the ability to find information critically. Digital literacy is the ability to use technology and information from digital devices effectively and efficiently [44]; the ability to use technology to find, evaluate, use, create and communicate information, with technical and cognitive skills [45]; ability to use digital technology well . From this understanding, digital literacy has several advantages, including; overcoming hoaxes in digital media and self-control [46], evaluating digital media [45], and controlling various content in cyberspace [47].

The factors that affect digital literacy include [48]: (1). the use of social media, the length of time media use will affect a person's digital literacy skills. The more often someone uses social media, the more information literacy skills can be in technical matters. (2). academic achievement, in general students' cognitive abilities affect the ability to select and process information (3). the role of parents. The role of the family indirectly affects digital literacy skills. Family also plays a role in character building in introducing the culture of reading [49] (4). reading intensity. Reading intensity can affect 
applicative digital literacy skills, because basically digital literacy is the absorption capacity of the use of digital information media to facilitate people's work, (5). Achievement Motivation [41], (6). Government policies [50] and schools [51,52].

Some recommendations for digital literacy development are: 1). strengthening the capacity of facilitators, this strengthening emphasizes training for schools, especially students, to utilize digital media in learning intelligently and wisely, 2). increasing the number and variety of quality learning resources. Science in the digital era is always being upgraded so fast and demands changes and the addition of new knowledge in the school environment. There are several things that schools can do to increase the number and variety of quality learning sources related to digital literacy, one of which is the addition of digital literacy reading materials in the library [53], 3) . Increasing public involvement as a reference for filtering needed information, such as Sharing Sessions or inviting experts to share how they apply digital technology in the professions of everyday life [7]. Stakeholder involvement in digital literacy, for example providing facilities and infrastructure $[19,52], 4)$. Using learning tools and learning media that are interesting and digital-based with guidance from parents and teachers. Children are accustomed to using digital devices so that children get used to and have control over themselves [54], 5). Inserting digital literacy material in the curriculum as an early learning effort [7], through habituation activities [10]; and repetition [55] carried out by all stakeholders such as schools, teachers and parents [56]. So that the concept of digital literacy will grow and become a skill for elementary school students in Malang City.

\section{CONCLUSION}

The digital literacy of elementary school students in Malang City gets a score of 3.07 which is in the sufficient category. Based on digital literacy indicators, elementary school students in Malang City have been able to seek information and yet are still lacking in information processing aspects from the internet. Digital literacy data is used as the basis for developing digital literacy programs for children, especially at the elementary school level, especially the emphasis on developing information processing from the internet. Digital literacy makes students wiser in using information and able to process information taken from the internet. In the development of digital literacy, elementary school students can be developed through several activities such as strengthening the capacity of facilitators, increasing the number and variety of quality learning sources, attractive media, increasing network access, increasing public and stakeholder engagement, and inserting digital literacy materials in the curriculum and habituation in House.

\section{ACKNOWLEDGMENTS}

We would like to thank Universitas PGRI Kanjuruhan Malang for their support.

\section{REFERENCES}

[1] APJII, Penetrasi \& profil perilaku pengguna internet indonesia, 2018.

[2] P.S. Breivik, 21st Century Learning And Information Literacy. University Library, 2005.

[3] K. Kumala, "Mobile Phone-Based Invertebrates Encyclopedia Fo Elementary School Students,” Int. J. Eng. Technol., vol. 5, no. 10, 2018.

[4] R. Sugihartati, Perkembangan Masyarakat Informasi Dan Teori Sosial Kontemporer. Jakarta: Kencana Prenada Media Group, 2014

[5] V.M. Day and S. Qodariah, "Menumbuhkan Literasi Digital Pada Anak Usia Sekolah 6-12 Tahun Increasing Digital Literation On 6-12 Years Old School-Age Children," Pengasuhan di Era Digit., vol. 2, no. 1, pp. 1-9, 2018.

[6] A. Kavanagh, "Digital Literacy : Why It Matters Digital Literacy: Why It Matters," Learn. Teach. Technol. Cent., pp. 1-13, 2016.

[7] Q.Q. Aýuni, "Literasi digital remaja di kota surabaya," Librinet, vol. 4, no. 2, pp. 224-239, 2015.

[8] M. Gipayana, "Pengajaran Literasi Dan Penilaian Portofolio Dalam Konteks Pembelajaran Menulis Di SD,” J. Ilmu Pendidik., vol. 11, no. 1, pp. 59-70, 2004.

[9] A. Aguslianto, Pengaruh Sosial Media Terhadap Akhlak Remaja. Universitas Islam Negeri Ar-Raniry Banda Aceh, 2017.

[10] S. Sutopo and P. Prasetyo, "Industri 4.0: Telaah Klasifikasi Aspek Dan Arah Perkembangan Riset," J. Tek. Ind., vol. 13, no. 1, 2018.

[11] L. Kibona and G. Mgaya, "Smartphones' Effects on Academic Performance of Higher Learnign Student: A case of Ruaha Cathiloc Universitu-Iringa, Tanzania,” J. Multidiscip. Eng. Sci. Technol., vol. 12, no. 4, pp. 777-784, 2015.

[12] N. Putri and B. Budiarti, "Pengaruh Media Sosial Terhadap Perilaku Remaja," Pros. KS Ris. PKM, vol. 3, no. 1, 2016.

[13] M.J. Stollak, A. Vandenberg, A. Burklund and S. Weiss, "Getting social: The impact of social networking usage on grades among college students," In Proceedings from ASBBS annual conference, vol. 18, no. 1, pp. 859-865, 2011.

[14] L. Pagani, G. Argentin, M. Gui, and L. Stanca, "The impact of digital skills on educational outcomes: evidence from performance tests," Educ. Stud., vol. 42, no. 21, pp. 137-162, 2016.

[15] E.W. Bernroider, B. Krumay and S. Margiol, "Not without my smartphone! Impacts of smartphone addiction on smartphone usage," ACIS, 2014.

[16] N. Pratiwi and P. Nola, "Pengaruh Literasi Digital Terhadap Psikolog Anak Dan Remaja,” J. Ilm. Progr. Stud. Pendidik. Bhs. Dan Sastra Indones., 2017

[17] M.W. Kurniawati and S. Anitah, "European Journal of Education Studies Developing Learning Science Teaching Materials Based On Scientific To Improve Students Learning,” Eur. J. Educ. Stud., vol. 3, no. 4, pp. 319-330, 2017.

[18] N.I. Fatmawati, “Literasi Digital, Mendidik Anak Di Era Digital Bagi Orang Tua Milenial,” Polit. J. Vol, Sos. Kemasyarakatan, vol. 11, no. 2 , pp. 119-138, 2019

[19] I.M. Sedana, "Guru Dalam Peningkatan Profesionalisme, Agen Perubahan Dan Revolusi Industri 4.0," J. Penjaminan Mutu Lemb. Penjaminan Mutu Inst. Hindu Dharma Negeri Denpasar, vol. 5, no. 2, pp. 179-189, 2017.

[20] I. von Behr, A. Reding, C. Edwards, and L. Gribbon, Radicalisation in the digital era, The use of the internet in 15 cases of terrorism and extremism. Washington DC: RAND Corporation, 2013.

[21] P. Gilster, Digital Literacy. New York: Wiley, 1997.

[22] Cornell University, Laptop Ergonomics-5 Tips for Using a Laptop Computer, 2009.

[23] S. Masitoh, "Blended Learning Berwawasan Literasi Digital Suatu Upaya Meningkatkan Kualitas Pembelajaram dan Membangun Generasi Emas 2045," Proc. ICECRS, vol. 1, no. 3, pp. 13-34, 2018 
[24] L. Liansari, "Realitas Penerapan Literasi Digital bagi Mahasiswa FKIP Universitas Muhammadiyah Sidoarjo," Procedings of The ICECRS, vol. 1 , no. 3 , pp. 241-252, 2018.

[25] H. Wahono and Y. Effrisanti, "Literasi Digital di Era Millenial," Pros. Semin. Nas. Has. Penelit. Pendidik. dan Pembelajaran STKIP PGRI Jombang, vol. 4, no. 1, pp. 185-193, 2018.

[26] M. Maulana, Definisi, Manfaat, Dan Elemen Penting Literasi Digital [Online]. Retreived from: http://Www.Muradmaulana.Com/2015/12/Definisi-Manfaat-Dan-Elemen-Penting-Literasi-Digital.Htm 2015.

[27] R. Retnawati, Validitas, Reliabilitas dan Karakteristik Butir. Jogjakarta: Parama Publisihing, 2016

[28] D. Bawden, "Literasi Digital Remaja Di Kota Surabaya," Areview Concepts. J. Doc., vol. 57, no. 2, pp. 218-259, 2001.

[29] M. Akbar and F. Anggreeni, "Teknologi dalam Pendidikan: Literasi Digital dan Self-Directed Learning Pada Mahasiswa Skripsi,” J. Indig., vol. 2, no. 1, 2017.

[30] S. Kajin, "Pengaruh Pembelajran Berbasis Literasi Digital Terhadap Motivasil Dan Hasil Belajar Kognitif Di Mts N Mojosari Dan Mtsn Sooko Mojokerto,” J. Islam. Reg. Instr., vol. 2, no. 1, 2018

[31] T. Rayahu and T. Mayasari, "Profil Kemampuan Awal Literasi Digital Dalam Pembelajaran Fisika Siswa SMK Kota Madiun," Semin. Nas. Quantum, pp. 2477-1511, 2018.

[32] S. Shariman and R. Razak, "Digital Literacy Competence For Academic Needs: An Analysis Of Malaysian Student In Three Universities," Elsevier Soc. Bevional Sci., pp. 1489-1496, 2012.

[33] S. Johnson, Everything Bad Is Good For You: How Today's Popular Culture Is Actually Making Us Smarter. New York: Riverhead Books, 2012.

[34] C. Geertz, The Interpretation of Cultures. New York: Basic Book, 1973.

[35] P. Phuapan, C. Viriyavejakul and P. Pimdee, "An Analysis of Digital Literacy Skills among Thai University Seniors," International Journal of Emerging Technologies in Learning, vol. 11, no. 3, 2016.

[36] A.P. Kahar, "Analisis Literasi Digital Mahasiswa Calon Guru Biolog Melalui Proyek Video Amatir Berbasis Potensi Lokal pada Mata Kuliah Ekologi Tumbuhan,” Pedagogi Hayati, vol. 2, no. 1, pp. 1-13, 2018

[37] P. Zhao, H. Kynäshlahti and S. Sintonen, "A qualitative analysis of the digital literacy of arts education teachers in Chinese junior high and high schools," Journal of Librarianship and Information Science, vol. 50, no. 1, pp. 77-87, 2018.

[38] M. Spante, S.S. Hashemi, M. Lundin and A. Algers, "Digital competence and digital literacy in higher education research : Systematic review of concept use," Cogent Educ., vol. 5, no. 1, pp. 1-21, 2018.

[39] W.A. Pratama and S. Hartini, "Analisis Literasi Digital Siswa Melalui Penerapan E-Learning Berbasis Schoology," vol. 06, no. 1, pp. 9-13, 2019
[40] W. Wahyudin and A. Cardina, "Analisis Literasi Digital Pada Konten Instagram @Infinitygenre,” WACANA, vol. 118, no. 1, pp. 25-34, 2019.

[41] K. Warno, "The factors influencing digital literacy of vocational high school teachers in Yogyakarta," In Journal of Physics: Conference Series, vol. 1446, no. 1, p. 012068, 2020.

[42] D. Hosseini, Digital Literacy in Early Elementary School: Barriers and Support Systems in the Era of the Common Core, 2018.

[43] S.S. Sari, "Kemampuan Literasi Digital Kalangan Siswa SMP dan SMA di Daerah Pedesaan Kabupaten Blitar," J. Chem. Inf. Model., vol. 53 no. 9, pp. 1689-1699, 2019.

[44] S. Herlina, Membangun Karakter Bangsa Melalui Literasi Digita [Online]. Retrieved from: http://staff.uny.ac.id/sites/default/files/pengabdian/dyna-herlina-suwartomsc/membangun-karakter-bangsa-melalui-literasi-digital.pdf, 2012.

[45] F. Salsabila, Pengaruh Literasi Ekonomi dan Literasi Digital Terhadap Perilaku Berwirausaha Sektor Kuliner yang Terdaftar pada Aplikasi Go Food di Pasar Segar Kota Makasar. Universitas Negeri Makasar, 2019.

[46] A. Sabrina, "Literasi Digital Sabagai Upaya Preventif Mennggulangi Hoax," J. Commun. Stud., vol. 5, no. 2, pp. 31-46, 2018

[47] A. Asyarotin, "Literasi Digital: Perilaku Digital Native dalam memanfaatkan Cloud Libary.," Pros. Semin. Nas. Prodi Ilmu Perpust. UM., 2018.

[48] R. Syah, D. Darmawan, and A. Purnawan, "Analisis faktor yang mempengaruhi kemampuan literasi digital," AKRABI, vol. X, no. 2, pp. 60-69, 2019.

[49] B. Blummer, "Digital literacy practices among youth populations: A review of the literature," Educ. Libr. Child. Resour., vol. 31, no. 3, pp. 38-45, 2008

[50] A. Baggia, A. Znidarsic, M.K. Borstnar, A. Pucihar, A. Sorgo, T. Bartol, and D. Dolnicar, "Factors influencing the Information Literacy of Students: Preliminary Analysis," In Bled eConference, pp. 2, 2016

[51] G.W. Mahinda, Factors Influencing Public Primary Schools' Implementation Of Digital Literacy Program: A Case Of Nakuru North Sub County, Nakuru County- Kenya. BY, 2018.

[52] A.D. Agbo, "Internet Literacy Skills Of Faculty: Academic Staff Members In UniversitY,” Int. J. Digit. Libr. Serv., vol. 1142, pp. 101$109,2014$.

[53] Goverment of Republic of Indonesia, Ministry of National Education, Standar Kualifikasi Akademik dan Kompetensi Guru. Indonesia: The Government of Republic of Indonesia.

[54] L.E. Truitt, Digital Literacy Devices in the Elementary Classroom, 2012.

[55] T. Trianto, Mendesain Model Pembelajaran Inovatif - Progresif. Konsep, Landasan dan Immpelemntasinya Pada KTSP. Jakarta: Kencana Media Prenada Group, 2012.

[56] E.Z. Nuroh and V. Liansari, "Digital age literacy in elementary school," In 1st International Conference on Intellectuals' Global Responsibility (ICIGR 2017) (pp. 119-123). Atlantis Press, 2018. 